\title{
脊䯣性痙性麻痺に於ける下肢運動機能の簡易的評価の試み
}

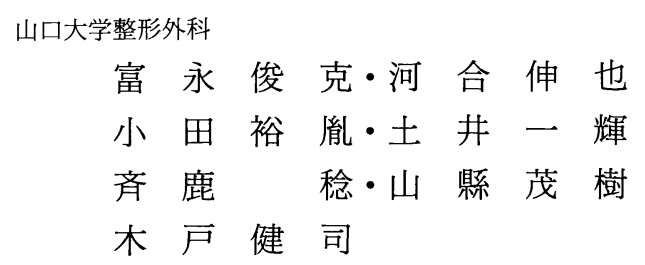

\section{A Clinical Evaluation for Motor Function of Lower Extrimities in Spinal Spasticity}

by

\section{Toshikatsu Tominaga, Shinya Kawai, Hirotsugu Oda, Kazuteru Doi, Minoru Saika, Shigeki Yamagata and Kenji Kido}

Department of Orthopedic Surgery, Yamaguchi University School of Medicine

\begin{abstract}
We postulated a new clinical quantitative evaluation method for motor function of the lower extremities in spinal spasticity: as knee and ankle 10 seconds test. This test is simply a measurement of the numbers of active flexion and extention of knee joint on supine position, and active dorsi-flexion and planter-flexion of ankle joint on supine position with knee extention.

This knee and ankle 10 seconds test had good correlation with total points and motor function of the lower extrimities evaluated by the JOA score.
\end{abstract}

目的

春髄性痙性麻痺における下肢運動機能を定量的に評 価することは, 診断学としての春䯣症の病態把握に加 えて，治療効果の判定にも有用である，今回私達は， 脊髄性痤性麻痺における下肢運動機能の簡易評価法と して, 10 秒間に行い得る膝および足関節の自動屈伸回 数（以下，膝·足 10 秒テスト）を測定し, 日本整形外 科学会䅡椎症性脊髄症治療判定基準 (以下, JOA スコ アー）と比較し，定量性について検討しているので報 告する.

\section{対象}

コントロールは, 神経症状の見られない 10 才から 70 才台の各 5 人, 合計 35 人である. 対象は, 脊髄性 痤性麻疩 62 例であり, 男性 41 例, 女性 21 例で, 年
令は 18 才から 79 才，平均 56 才である。疾患の内訳 は, CSM 24 例, OPLL 症 18 例, 脊髄腫崵 12 例, 脊 髄空洞症 8 例である。

\section{評価法}

臥位にて, 10 秒間に最大努力にて行い得る膝と足 関節の自動屈伸回数を両下肢について 3 回程測定し, 屈伸を 1 回, 屈曲と伸展のみは各 0.5 回として, その 最大回数を膝・足 10 秒テスト值として評価した。足 10 秒テストは，滕伸展位にて行い，ROMについては 充分な背屈が出来なくても, その回数を 10 秒テスト 值として評価した。

この滕・足 10 秒テストの評価值を左右の最大値, 最 小值, 平均值別に神経症状, JOA 総点および JOA 下 肢運動機能点数と比較検討した. 


\section{結果}

コントロールの膝・足 10 秒テスト結果では, 膝, 足 関節の屈伸回数は，高令者になる程小さな值をとる傾 向が見られ，20から 50 才台での正常下限は，およそ 膝が 12 回で，足が 23 回である.

膝・足 10 秒テスト值の左右差が腱反射の六進や病的 反射などの神経症状 (pyramidal tract sign) の左右差 を検出する sensitivityと specificityは, 優位水準 0.001 にて，それぞれ $85 \%$ と $88 \%$ である.

膝・足 10 秒テスト值と JOA スコア一の相関は 10 秒テストの最大, 最小值別の相関よりも左右の平均值 との相関が最も高かった。

膝・足 10 秒テストの左右平均値と JOA 総点の相関 は，優位水準 0.0001 にて，相関係数がそれぞれ 0.72 と 0.76 である.一方, 膝・足 10 秒テストの左右平均 值と JOA 下肢運動機能点との相関係数は, 優位水準 0.0001 にて，それぞれ 0.82 と 0.82 である.

JOA 総点は, 膝・足 10 秒テストの平均値により, 重 相関係数 0.8 , 誤差 \pm 0.6 の範囲で, $3.8+0.28 \times$ 膝テス 卜值 $+0.34 \times$ 足テスト值として,さらに JOA 下肢運 動機能点は, 重相関係数 0.8 誤差士0.3の範囲に て, $-0.65+0.19$ 膝テスト值 +0.58 足テスト值とし て，概ね予測できる。

\section{考察}

脳卒中に伴う片麻痺の歩行予後は, 障害側の下肢運 動機能から概ね予測できるとされている，即ち，空中 屈伸が可能であれば独歩か悪くても一本杖歩行が予測 でき, 立膝の予後は歩行可能か否かの境である1). 一 方，脊髄性痙性麻痺においては，程度の差があるもの の殆ど両下肢が障害を受け, 脳卒中とは異なる歩行様 式をとるため，この方程式は成り立たない。

䅡髄症では, Myelopathy handとして, finger escape signの程度と 10 秒間に行い得る grip and releaseの回数は重症度を反映するとされる2).この 臨床的事実から, pyramidal tractの障害の程度は, 手指に加えて下肢にも影響を及ぼすであろうと推察し て，今回下肢の運動について調査を試みた。

今回の調查では, 脊髄症の重症度が進むにつれて, 下肢の運動は，まず始めに足趾の開閉や足関節の背屈 が困難となり, 足趾の屈曲変形をよく観察できたが, finger escape sign に対応するような足趾の特徵的所 見は明らかにはできなかった。一方, 滕・足 10 秒テス トはJOA スコアーとかなり高い相関を示した.しか し，高令者や痛みのある例での屈伸回数は神経症状に 比較して少ない值を取る傾向がある一方，深部知覚障 害が強い症例では屈伸回数が多いにも拘わらず歩行困 難例があり，評価にあたっては注意が必要である.

膝・足 10 秒テストは，再現性や年令による問題を有 するものの, 方法が簡単であり, JOA スコアーとも 良く相関する，臥床患者の運動機能の評価やリハビリ 効果の判定にも有用であると考えている.

\section{ま と め}

下肢運動機能の簡易な定量的評価法として，コント ロール 35 人と脊髄性痙性麻痺 62 例について, 膝・足 10 秒テストを行い, JOA スコアーと比較検討した.

膝・足 10 秒テストは，再現性や年令による問題点を 有するものの, 歩行能力や神経機能全体の JOA とも 良く相関しており，簡易な定量的評価法として有用で あると考えている.

\section{文献}

1）服部一郎：椿·里吉編, 臨床神経病学最近の進歩, 医 歯薬出版, 432, 1965.

2) Keiro Ono et al. Myelopathy hand. Spine 1987 : 69-B : 215-9. 